\title{
Effect of Hybrid Type on Fermentation and Nutritional Parameters of Whole Plant Corn Silage
}

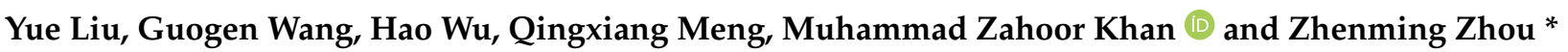 \\ State Key Laboratory of Animal Nutrition, College of Animal Science and Technology, China Agricultural \\ University, Beijing 100193, China; yueliu@cau.edu.cn (Y.L.); wgy1341549373@163.com (G.W.); \\ wu2213@cau.edu.cn (H.W.); qxmeng0624@126.com (Q.M.); zahoorcau@cau.edu.cn (M.Z.K.) \\ * Correspondence: zhouzm@cau.edu.cn; Tel.: +86-010-6273-126-8
}

Citation: Liu, Y.; Wang, G.; Wu, H.; Meng, Q.; Khan, M.Z.; Zhou, Z. Effect of Hybrid Type on Fermentation and Nutritional Parameters of Whole Plant Corn Silage. Animals 2021, 11, 1587. https://doi.org/10.3390/ ani11061587

Academic Editors: Dirk von Soosten and Manuel Fondevila

Received: 7 May 2021

Accepted: 25 May 2021

Published: 28 May 2021

Publisher's Note: MDPI stays neutral with regard to jurisdictional claims in published maps and institutional affiliations.

Copyright: (c) 2021 by the authors. Licensee MDPI, Basel, Switzerland. This article is an open access article distributed under the terms and conditions of the Creative Commons Attribution (CC BY) license (https:/ / creativecommons.org/licenses/by/ $4.0 /)$.
Simple Summary: Two corn hybrid types, dual-purpose and silage-specific, were harvested at the one half to three fourths milk line and ensiled in fermentation bags for 60 days. Parameters such as fermentation quality, chemical composition, yield prediction and energy value, carbohydrate profile, and in situ digestibility were evaluated for the comparison of two corn types. Our analysis for the above parameters showed that under favourable production conditions, for whole-plant corn silage, the nutritive value per unit was higher for dual-purpose corn, but biomass yield and nutritive value per ha were higher in silage-specific corn. Our current study provides data for whole-plant corn silage research and reference data for ruminant nutrition in selecting corn silage.

Abstract: This study was designed to evaluate the effect of hybrid type on the fermentation and nutritional parameters of whole-plant corn silage (dual-purpose and silage-specific corn). For this purpose, the two corn hybrid types were harvested at the one-half to three-fourths milk line and ensiled in fermentation bags $(50 \times 80 \mathrm{~cm})$ for 60 day. Our results demonstrated that the ratio of lactic acid to acetic acid $(p=0.004)$, propionic acid $(p<0.001)$, Flieg point $(p<0.001)$, ether extract $(p=0.039)$, starch $(p<0.001)$, milk-per-ton index $(p<0.005)$, net energy for lactation $(p=0.003)$, total digestible nutrients $(p<0.001)$, neutral detergent soluble fiber $(p=0.04)$, and in situ dry matter digestibility $\left(\mathrm{TDMD}_{\mathrm{is}}\right)(p<0.001)$ were higher in dual-purpose corn silage, while the $\mathrm{pH}(p=0.014)$, acetic acid $(p=0.007)$, the ratio of ammonia nitrogen to total nitrogen $(p=0.045)$, neutral detergent fiber $(p<0.001)$, acid detergent fiber $(p<0.001)$, acid detergent lignin $(p<0.001)$, dry matter yield per ha $(p<0.001)$, milk-per-acre index $(p=0.003)$, available neutral detergent fiber $(p<0.001)$, and unavailable neutral detergent fiber $(p<0.001)$ were higher in silage-specific corn silage. Based on our analysis, we concluded that under favourable production conditions for whole-plant corn silage, the nutritive value per unit was higher in dual-purpose corn while biomass yield and nutrient value per ha were higher in silage-specific corn.

Keywords: hybrid type; dual-purpose corn; silage-specific corn; nutritive value; yield prediction and energy value; in situ digestibility

\section{Introduction}

Corn (Zea mays L.) silage is an important fiber and energy source for ruminants [1]. Whole-plant corn silage (WPCS) has been widely used in ruminant nutrition to improve their production performance, e.g., dry matter intake [2], average daily gain [3], and milk yield [3,4]. With the progress of technology, corn yield has rapidly improved in China. The grain corn has been in surplus for the past ten years in China; however, the volume of imported forage has been increased [5]. Therefore, the Chinese government has encouraged the production of WPCS since 2015.

The effect of corn hybrid types on the quality of WPCS has been studied. Sheaffer et al. [6] compared the yield and quality among brown midrib (BMR), leafy (LFY), and 
conventional (CON) corn silage. Ferraretto et al. [7] reported the fermentation and digestibility of corn silage among BMR compared with dual-purpose or LFY. However, there are few comparative studies of WPCS from dual-purpose corn and LFY corn $[8,9]$ and no study that compares WPCS from dual-purpose corn and silage-specific corn has been reported. Thomas et al. [8] demonstrated that dual-purpose and LFY corn silages have similar contents of fiber, starch, in vitro true dry matter disappearance $\left(\mathrm{TDMD}_{\mathrm{vt}}\right)$, in vitro $\mathrm{NDF}$ disappearance $\left(\mathrm{NDFD}_{\mathrm{vt}}\right), \mathrm{pH}$, and lactic acid concentration at similar content of DM. Similarly, Ballard et al. [9] reported a higher NDFD $_{\mathrm{vt}}$ for LFY than dual-purpose corn silage at similar maturities and moisture content. On the other hand, it has been reported that the quality of corn silage can vary due to differences in the quantity of grain and quality of stover present between hybrids [10,11]. Additionally, dual-purpose corn allows growers to harvest the crop as either grain or silage. Conversely, the silage-specific corn is characterized by tall plants and stay-green that contains a high forage yield and low proportion of grain components.

Therefore, the objective of this study was to evaluate the effect of hybrid types (dualpurpose and silage-specific corn) on fermentation quality, chemical composition, yield prediction and energy value, carbohydrate profile, and in situ digestibility of whole plant corn silage.

\section{Materials and Methods}

\subsection{Ensiling of Whole-Plant Corn}

The ensiling process of whole-plant corn silage hybrid types was conducted at the Beef Cattle Research Center at the China Agricultural University, Beijing. The dual-purpose and silage-specific corn hybrids were harvested in Tianjin and Shanxi at a seeding rate of 55,000 plants/ha and 65,000 plants/ha, respectively (Table 1). Corn was cut at the one-half and three-fourths milk lines on 29 August and 9 September 2016, respectively. Twenty plants of each variety were manually cut at approximately $10-15 \mathrm{~cm}$ above the ground. Four plants were harvested from each of five different sites within an experimental plot, resulting in twenty plants per corn hybrid. Fresh weights of individual plants were recorded, and then chopped using a hammer crusher (Changhong-330, Henan Xingyang Changheng Machinery Factory, Henan, China) with a theoretical cut length of 1-2 cm, and a $300 \mathrm{~g}$ sample from each hybrid was removed for DM analysis. The yield of each hybrid was calculated by including the contribution of the twenty individual plants. Thereafter, the chopped plants (5 $\mathrm{kg}$, in triplicate) were immediately packed in fermentation bags with a one-way breathing valve $(50 \times 80 \mathrm{~cm}$, Xinyu scarecrow agricultural park, Jiangxi, China) and vacuum sealed (DZ-2SE, Dongguan Qingye Packaging Machinery Ltd. Co., Guangdong, China). The plants were allowed to ferment at room temperature for 60 days. No silage inoculant was used during ensiling. The filling, compressing, and sealing processes were the same for both corn types.

Table 1. Information on types and varieties of corn.

\begin{tabular}{cccc}
\hline Corn Types & Varieties & Location & Plants/ha \\
\hline Dual-purpose & Luyu 36, Wofeng 9, Zhengdan 958, Jingke 25, Jiyuan 128, & & \\
corn & Derun 98, Jundan 128, Jiudan 100, Jiudan 25, Wurui 605, & Tianjin & 55,000 \\
(19 corn varieties) & Dongyu 108, Jiudan 57, Xianfeng 32D22, Weifeng 6, & & \\
Silage-specific & Xinyu 35, Huanong 866, Songyu 656, Jindan 52, Jundan 20 & & \\
corn & Yu Silage 23, Zheng Silage 1, Dafeng Silage 1, Beinong & \multirow{2}{*}{ Shanxi } & 65,000 \\
(13 corn varieties) & Silage 356, QS5, V80, HC45, QS3, Dafengsiyu 12, HC46, & & \\
\hline
\end{tabular}

\subsection{Fermentation Quality}

A subsample of $30 \mathrm{~g}$ (in triplicate) was weighed in a blender (FS-2, Changzhou Xinhang Instrument Factory, Jiangsu, China), diluted with $300 \mathrm{~mL}$ distilled water, homogenized for 2 min and passed through four layers of cheesecloth. The extracted solution's $\mathrm{pH}$ was 
measured using an electrode (PHS-3C, Shanghai Leici Instrument Factory, Shanghai, China). The filtrate $(20 \mathrm{~mL})$ was stored at $-20{ }^{\circ} \mathrm{C}$ for further analyses. The ammonia nitrogen $\left(\mathrm{NH}_{3}\right.$ $\mathrm{N}$ ) was determined according to the phenol-sodium hypochlorite colorimetric method (Broderick and Kang, 1980) using a spectrophotometer (UV-VIS 8500, Tianmei Scientific Instrument Co., Shanghai China), and the total nitrogen was determined using the Dumas combustion method (RaPid N III, Elementar, Germany). We analyzed lactic acid by ion chromatography (Dionex ICS-2500, Dionex instruments, California, CA, USA) equipped with an InoPac AS11-HC analysis column $(4 \times 250 \mathrm{~mm})$, an InoPac AS11-HC protect column $(4 \times 50 \mathrm{~mm})$, and an ASRS ULTRA II $4 \mathrm{~mm}$ suppressor. The sampling amount was $25 \mu \mathrm{L}$, the column temperature was $30^{\circ} \mathrm{C}$, the mobile phase was $50 \mathrm{mml} / \mathrm{L}$ sodium hydroxide solution and ultrapure water, and had a flow rate of $1 \mathrm{~mL} / \mathrm{min}$. VFA was analyzed by gas chromatography (SP-3420, Beijing Analytical Instrument Factory, Beijing, China) (Yan L and Qing X., 2006). The Flieg point was calculated using the following equation: Flieg point $=220+(2 \times \mathrm{DM} \%)-15-(40 \times \mathrm{pH})$, and a Flieg point of 100-81, 80-61, 60-41, 40-21, and 20-0 represent excellent, good, medium, low, and poor silage quality, respectively [12].

\subsection{Chemical Composition}

The second subsample of $300 \mathrm{~g}$ was air-dried in a cool, ventilated place, and ground using a feed mill (DF-20, Wenling Linda machinery co. LTD, Zhejiang, China) to a particle size of $1 \mathrm{~mm}$ for further analyses. Then, samples were analyzed for DM (method 930.15), and ash (method 942.05) using the AOAC method [13]. Furthermore, the starch was analyzed using a total starch assay kit (Megazyme, Bray, Ireland; method 996.11) based on the AOAC method [13]. The nitrogen was analyzed using the Dumas combustion method (RaPid N III, Langenselbold, Germany). In addition, the CP was calculated using a 6.25 nitrogen-to-protein conversion factor. The ether extract (EE) was obtained using an automatic extractor (ANKOM XT101, ANKOM Technology Corp., Macedon, NY, USA). The determination of NDF, ADF, and acid detergent lignin (ADL) was performed according to the method reported by Van Soest et al. [14] and Robertson et al. [15] with heat-stable $\alpha$-amylase, and performed using a fiber analyzer (ANKOM A220, ANKOM Technology Corp., Macedon, NY, USA). The water-soluble carbohydrate (WSC) was determined by anthrone-sulfuric acid colorimetry [16].

\subsection{Yield Prediction and Energy Value}

The DM yield was estimated according to the fresh weight per plant and the loss of DM ensiling. The milk-per-ton index (MT), milk-per-acre index (MA), and $\mathrm{NE}_{\mathrm{L}}$ were calculated using the Milk 2006 model developed by the University of Wisconsin. The calculation of total digestible nutrients (TDN) was performed as reported by Weiss [17]. The composition was expressed on a DM basis (\%).

$$
\begin{gathered}
\mathrm{TDN}(\%)=0.98 \times\left(100-\mathrm{NDF}_{\mathrm{N}}-\mathrm{CP}-\mathrm{Ash}-\mathrm{IADICP}\right. \\
-\mathrm{EE})+\mathrm{K}_{\mathrm{dCP}} \times \mathrm{CP}+2.25 \times(\mathrm{EE}-1)+0.75 \times\left(\mathrm{NDF}_{\mathrm{N}}\right. \\
-\mathrm{ADL} \times\left[1-\left(\mathrm{ADL} / \mathrm{NDF}_{\mathrm{N}}\right)^{0.667}\right]-7 \\
\mathrm{NDF}_{\mathrm{N}}=\mathrm{NDF}-\mathrm{NDICP}+\mathrm{IADICP} \\
\mathrm{IADICP}=0.070 \times \mathrm{ADICP} \\
\mathrm{K}_{\mathrm{dCP}}=\exp (-0.0012 \times \mathrm{ADICP})
\end{gathered}
$$

\subsection{Carbohydrate Profile}

The carbohydrate composition profile (except unavailable neutral detergent fiber, CC) was calculated according to the equations as described by NRC (2016) [18], CC was calculated according to Sniffen et al. [19]. The composition was expressed on a DM basis (\%).

Non-neutral detergent fiber (non-NDF) $=100-\mathrm{CP}-\mathrm{NDF}-\mathrm{EE}-\mathrm{Ash}$ 
Organic acid $(\mathrm{OA})=$ lactic acid + acetic acid + propionic acid + butyric acid + other OA Water-soluble carbohydrate $(\mathrm{CA})=$ WSC

$$
\mathrm{CB} 1=\text { starch }
$$

Neutral detergent soluble fiber $(\mathrm{CB} 2)=$ non-NDF $-\mathrm{OA}-\mathrm{CA}-\mathrm{CB} 1$

Unavailable neutral detergent fiber $(\mathrm{CC})=2.4 \times \mathrm{ADL}$

Available neutral detergent fiber $(\mathrm{CB} 3)=\mathrm{NDF}-\mathrm{CC}$

\subsection{In Situ Digestibility}

The digestibility of corn silage was determined by the in situ nylon bag technique reported by Fei et al. [20]. Three Angus steers (380 $\pm 15 \mathrm{~kg}$ live weight) fitted with permanent rumen cannulas (Beef Cattle Research Center, China Agricultural University, Beijing, China) were used in this study, and the animals were approved by the China Agricultural University Animal Care and Use Committee (AW06059102-2, Beijing, China). The animals were fed a total mixed ration at 8:00 and 17:00 according to NRC (2000) [21] and had ad libitum access to drinking water and a mineral block. Each sample $(4.00 \pm 0.01 \mathrm{~g})$ was transferred to a single nylon bag $(80 \times 140 \mathrm{~mm}$; Beef Cattle Research Center, China Agricultural University) with a pore size of $37 \mu \mathrm{m}$. Each type of corn silage had nine nylon bags, three nylon bags placed in each cattle, and then samples were incubated in the rumen for 24 or $48 \mathrm{~h}$. Following their removal, the bags were immediately rinsed in cold water and washed 6 times ( $1 \mathrm{~min} /$ rinse) in a washing machine until the water became clear and then dried at $105^{\circ} \mathrm{C}$ for $48 \mathrm{~h}$ for in situ dry matter digestibility (TDMD is $)$ analysis, and dried at $65^{\circ} \mathrm{C}$ for $48 \mathrm{~h}$ for in situ neutral detergent fiber digestibility (NDFD is) analysis.

\subsection{Statistical Analysis}

The statistical analysis was performed using SAS 9.0 software (SAS Institute Inc., Cary, NC, USA), and a two-tailed Student's t-test [22] was used for comparison between the two corn types. A significant difference was considered as $p<0.05$.

\section{Results}

\subsection{Fermentation Parameters}

The fermentation parameters of dual-purpose and silage-specific corn silage are presented in Table 2. Our results demonstrated that the dual-purpose corn silage contained more propionic acid $(p<0.001)$, had a higher Flieg point $(p<0.001)$, and the ratio of lactic acid to acetic acid $(p=0.004)$ was also higher than the silage-specific corn silage. Consistently, the silage-specific corn silage contained higher acetic acid $(p=0.007), \mathrm{pH}$ $(p=0.014)$, and ratio of ammonia nitrogen to total nitrogen $(p=0.045)$. Additionally, following $60 \mathrm{~d}$ of fermentation, $\mathrm{pH}$ values ranged between 3.84 and 3.88. The ratio of lactic acid to acetic acid was $>3: 1$, while no butyric acid was detected. Finally, we also documented that the Flieg points were greater than 108.00 points in our current experiment.

Table 2. Fermentation parameters of dual-purpose and silage-specific corn silage.

\begin{tabular}{|c|c|c|c|c|}
\hline Item $^{1}$ & Dual-Purpose Corn & Silage-Specific Corn & SEM $^{3}$ & $p$-Value \\
\hline $\mathrm{pH}$ & 3.84 & 3.88 & 0.01 & 0.014 \\
\hline Lactic acid, $\%$ & 4.86 & 5.06 & 0.31 & 0.640 \\
\hline Acetic acid, \% & 1.02 & 1.38 & 0.08 & 0.007 \\
\hline Propionic acid, \% & 0.12 & 0.03 & 0.01 & $<0.001$ \\
\hline Lactic acid:acetic acid & 5.25 & 3.67 & 0.33 & 0.004 \\
\hline Butyric acid, $\%$ & $\mathrm{ND}^{2}$ & ND & - & - \\
\hline $\mathrm{NH}_{3}-\mathrm{N} / \mathrm{TN}, \%$ & 3.73 & 4.39 & 0.20 & 0.045 \\
\hline Flieg point ${ }^{3}$ & 117.95 & 108.60 & 1.80 & $<0.001$ \\
\hline
\end{tabular}

${ }^{1}$ Lactic acid: Acetic acid $=$ the ratio of lactic acid and acetic acid; $\mathrm{NH}_{3} \mathrm{~N} / \mathrm{TN}=$ the ratio of ammonia nitrogen to total nitrogen; ${ }^{2} \mathrm{ND}=$ not detected; ${ }^{3}$ Flieg point $=220+(2 \times \mathrm{DM} \%-15)-(40 \times \mathrm{pH}) ;{ }^{3}$ SEM: standard error of the mean. 


\subsection{Chemical Composition}

There were significant differences $(p<0.01)$ in the DM, starch, NDF, ADF, and ADL between the two corn silages, as mentioned in Table 3. Consistently, our data reported a significant difference for EE $(p=0.039)$ between the dual-purpose and silage-specific corn silages. Consequently, our results have shown that the percentage compositions of starch and EE were higher in the dual-purpose silage than in the silage-specific corn silage. In contrast, the NDF, ADF, and ADL were higher in the silage-specific corn silage in comparison to the dual-purpose corn silage (Table 3).

Table 3. Chemical compositions of the dual-purpose and the silage-specific corn silage (DM basis).

\begin{tabular}{ccccc}
\hline Item $^{\mathbf{1}}$ & Dual-Purpose Corn & Silage-Specific Corn & SEM $^{\mathbf{2}}$ & $p$-Value \\
\hline DM, \% & 33.34 & 29.37 & 1.04 & 0.009 \\
CP, \% & 8.73 & 8.82 & 0.15 & 0.702 \\
EE, \% & 2.38 & 2.08 & 0.10 & 0.039 \\
Starch, \% & 27.75 & 22.90 & 0.78 & $<0.001$ \\
WSC, \% & 2.26 & 2.29 & 0.19 & 0.323 \\
NDF, \% & 43.12 & 50.34 & 0.71 & $<0.001$ \\
ADF, \% & 22.49 & 25.97 & 0.45 & $<0.001$ \\
ADL, \% & 2.47 & 3.14 & 0.10 & $<0.001$ \\
Ash, \% & 4.90 & 4.88 & 0.21 & 0.951 \\
\hline
\end{tabular}

${ }^{1} \mathrm{DM}=$ dry matter; $\mathrm{CP}=$ crude protein; $\mathrm{EE}=$ ether extract; $\mathrm{WSC}=$ water soluble carbohydrate; NDF = neutral detergent fiber; $\mathrm{ADF}=$ acid detergent fiber; $\mathrm{ADL}=$ acid detergent lignin; $^{2} \mathrm{SEM}$ : standard error of the mean .

\subsection{Yield Production and Energy Value}

Yield production and energy value of the dual-purpose and silage-specific corn silages are summarized in Table 4 . Our findings showed that the significant difference $(p<0.001)$ in DM yield, MA, TDN, MT ( $p=0.005)$, and $\mathrm{NE}_{\mathrm{L}}(p=0.003)$. In addition, the DM yield and MA were higher in silage-specific corn silage, but the $\mathrm{MT}, \mathrm{NE}_{\mathrm{L}}$, and $\mathrm{TDN}$ were lower compared to the dual-purpose corn silage.

Table 4. Yield prediction and energy values of the dual-purpose and silage-specific corn silages.

\begin{tabular}{ccccc}
\hline Item $^{\mathbf{1}}$ & Dual-Purpose Corn & Silage-Specific Corn & SEM $^{\mathbf{2}}$ & $p$-Value \\
\hline DM yield, & 13.35 & 21.51 & 0.751 & $<0.001$ \\
ton/ha & 1.26 & 1.15 & 0.027 & 0.005 \\
$\mathrm{MT}$, ton/ton & 16.79 & 24.42 & 0.704 & $<0.001$ \\
$\mathrm{MA}$, ton $/ \mathrm{ha}$ & 0.33 & 0.31 & 0.004 & 0.003 \\
$\mathrm{NE}_{\mathrm{L}}, \mathrm{MJ} / \mathrm{kg}$ & 71.84 & 68.36 & 0.511 & $<0.001$ \\
$\mathrm{TDN}$ & &
\end{tabular}

${ }^{1} \mathrm{DM}$ yield $=$ dry matter yield; $\mathrm{MT}$ = milk-per-ton index; $\mathrm{MA}=$ milk-per-acre index; $\mathrm{NE}_{\mathrm{L}}$ = net energy for lactation; TDN = total digestible nutrients; ${ }^{2}$ SEM: standard error of the mean.

\subsection{Carbohydrate Profile}

As presented in Table 5 , the significant differences $(p<0.001)$ for CB1, CB3, CC, and CB2 $(p=0.04)$ were recorded between the dual-purpose and silage-specific corn silages. In addition, the CB1 and CB2 were higher $(p<0.05)$ in the dual-purpose corn silage, whereas the CB3 and CC were higher $(p<0.001)$ in the silage-specific corn silage. 
Table 5. Carbohydrate profile of the dual-purpose and silage-specific corn silages (DM basis).

\begin{tabular}{ccccc}
\hline Item $^{\mathbf{1}}$ & Dual-Purpose Corn & Silage-Specific Corn & SEM $^{\mathbf{2}}$ & $\boldsymbol{p}$-Value \\
\hline OA, $\%$ & 5.99 & 6.46 & 0.35 & 0.332 \\
CA, \% & 2.26 & 2.29 & 0.19 & 0.923 \\
CB1, \% & 27.75 & 22.90 & 0.78 & $<0.001$ \\
CB2, \% & 4.91 & 2.94 & 0.66 & 0.040 \\
CB3, \% & 37.18 & 42.80 & 0.63 & $<0.001$ \\
CC, \% & 5.94 & 7.54 & 0.23 & $<0.001$ \\
\hline
\end{tabular}

${ }^{1} \mathrm{OA}$ = organic acid; WSC = water soluble carbohydrate; $\mathrm{CB} 1$ = starch; $\mathrm{CB} 2$ = neutral detergent soluble fiber; CB3 = available neutral detergent fiber; $\mathrm{CC}=$ unavailable neutral detergent fiber; ${ }^{2}$ SEM: standard error of the mean.

\subsection{In Situ Digestibility}

Our data showed a significant difference $(p<0.001)$ for in situ DM digestibility (Table 6). Specifically, the TDMD is at $24 \mathrm{~h}(55.21 \%)$ and $48 \mathrm{~h}(71.82 \%)$ in the dual-purpose corn silage was comparatively higher than that of the silage-specific corn silage at $24 \mathrm{~h}$ $(47.33 \%)$ and $48 \mathrm{~h}(61.57 \%)$. However, no difference was reported for the $\mathrm{NDFD}_{\text {is }}$ at $24 \mathrm{~h}$ and $48 \mathrm{~h}$ between the two corn silages.

Table 6. In situ digestibility of the dual-purpose and silage-specific corn silages (DM basis).

\begin{tabular}{ccccc}
\hline Item $^{\mathbf{1}}$ & Dual-Purpose Corn (\%) & Silage-Specific Corn (\%) & SEM $^{\mathbf{2}}$ & $p$-Value \\
\hline $24 \mathrm{~h} \mathrm{TDMD}_{\text {is }}$ & 55.21 & 47.33 & 0.89 & $<0.001$ \\
$48 \mathrm{hDMD}_{\text {is }}$ & 71.68 & 61.57 & 0.75 & $<0.001$ \\
$24 \mathrm{~h} \mathrm{NDFD}_{\text {is }}$ & 21.57 & 22.01 & 0.63 & 0.634 \\
$48 \mathrm{~h} \mathrm{NDFD}_{\text {is }}$ & 46.87 & 44.74 & 0.89 & 0.102 \\
\hline
\end{tabular}

${ }^{1} \mathrm{TDMD}_{\text {is }}=$ in situ dry matter digestibility; $\mathrm{NDFD}_{\text {is }}=$ in situ neutral detergent fiber digestibility [23]; ${ }^{2}$ SEM: standard error of the mean.

\section{Discussion}

This experiment was designed based on the actual production of dual-purpose corn and silage-specific corn with samples collected from actual corn production. A large number of corn hybrid varieties were collected for two corn types, a good representation for each type of corn. To compare the dual-purpose and silage-specific corn silages in this study, we harvested two types of corn at the same stage. After analyzing, we observed a good fermentation quality between the two corn silages. Moreover, the dual-purpose corn silage has a higher ratio of lactic acid to acetic acid, propionic acid, Flieg point, EE, starch, MT, TDN, $\mathrm{NE}_{\mathrm{L}}, \mathrm{CB} 2$, and $\mathrm{TDMD}_{\text {is }}$, and lower $\mathrm{pH}$, acetic acid, $\mathrm{NH}_{3}-\mathrm{N} / \mathrm{TN}, \mathrm{NDF}$, $\mathrm{ADF}, \mathrm{ADL}$, DM yield per ha, MA, CB2, and CB3 compared to the silage-specific corn silage.

A lower $\mathrm{pH}$ value is usually an indicator of increased lactic acid concentration, thereby implying better fermentation of silages during the ensiling period; our results both fall into the 3.80 to 4.20 range [24]. The acetic acid in silage results from the fermentation of sugar by heterofermentative lactic bacteria and intestinal bacteria [25], which is the most abundant organic acid produced by ideal fermentation; our results were within the recommended value (4-6\%) [18], similar to Nennich et al. [26], suggesting the corn was well fermented in this experiment. The lower ratio of lactic acid to acetic acid [18] also suggests ideal fermentation conditions in the present study. Additionally, the $\mathrm{NH}_{3}-\mathrm{N} / \mathrm{TN}$ indicates the degradation of $\mathrm{CP}$, which is far below $10 \%$, suggesting that both corn silges were well fermented in the current study [3]. The butyric acid was not detected in this experiment, which is in line with the findings reported by Zhou et al. [27]. They argued that butyric acid concentration was low and biologically negligible in whole-plant corn silage. Therefore, for two corn silages, the higher Flieg points with excellent fermentation quality [12] might be due to being well vacuum-sealed. Brüning et al. [28] had reported that low compaction and delayed sealing adversely impacts silage quality.

Shaver et al. [29] reported that CON corn (34.30\%) has 6.5\% more DM content than BMR corn (32.20\%) at the one-half milk line, whereas Johnson et al. [30] found that a 
$7.70 \%$ difference of corn silage in DM content at the two-thirds milk line. In our findings, dual-purpose corn silage had $3.97 \%$ more DM content than silage-specific corn silage at the one-half to three-fourths milk lines ( $33.34 \%$ vs. $29.37 \%$, respectively). The difference in the DM between the two hybrid types might be ascribed to the different proportion of different parts of the plant: silage-specific corn has a higher proportion of leaves, stalks, and is lower in grain content than dual-purpose corn [8]. Xu et al. [31] also observed that the different plant parts of corn silage had an impact on the DM content and the proportion of cob and grain was significantly higher in dual-purpose corn than that of LFY corn, while the opposite results were obtained for leaves and stalks. A study reported a significant difference in the NDF and ADF between a leafy-nutridense corn silage and a yellow-dent corn silage [32]. It has been demonstrated that the differences in nutritional parameters may be because of the different parts of the plant with varying proportions of fiber [31]. It has been well studied that the starch is mainly present in the grain; thus, in our current study, we also reported a higher starch content in the dual-purpose corn silage compared to the silage-specific corn silage. Accordingly, a study also documented that the starch content was higher in $\mathrm{CON}$ hybrids than in high-biomass hybrids at three different harvest times [33]. In the future, studies may provide more information on selecting different harvest times with different corn hybrid types, when compared to chemical composition.

In our current study, we found higher MT and energy values in dual-purpose corn silage, but a lower DM yield per ha and MA in silage-specific corn silage, which might be due to the higher nutritive value per unit in dual-purpose corn silage and the higher biomass yield and nutritive value per ha in silage-specific corn silage. The carbohydrate compositions were divided into six fractions: OA, CA, CB1, CB2, CB3, and CC. [18]. The OA is the acid produced by fermentation and the organic acid that remained in raw materials, which is considered to be $100 \%$ digestible [34]. The CA is fully utilized in the rumen, while the CB1 is partially degraded and the CB3 is 20\% digestible [35]. The CB2 showed a rapid degradation ( $20 \%$ to $40 \%$ per hour), while the CC was not digestible in the rumen, small intestine, or posterior intestine [18]. The higher contents of CB1 and CB2 in the dual-purpose corn silage and the higher contents of CB3 and CC in the silage-specific corn silage suggest that the nutrient degradation rate of rumen for the dual-purpose corn silage was lower than the rumen degradation rate of silage-specific corn silage.

The $24 \mathrm{~h} \mathrm{TDMD}_{\text {is }}$ values in our study were similar to the result $(53 \%, 2 / 3$ milk line) obtained by Shaver et al. [29]. However, the $24 \mathrm{~h} \mathrm{NDFD}$ is values reported in the current study were much higher than the documented results of Shaver et al. [29]. In addition, the $48 \mathrm{~h} \mathrm{NDFD}_{\text {is }}$ values were higher than the $30 \mathrm{~h}_{\mathrm{NDFD}}$ is of Akins and Shaver [4]. These differences are mainly ascribed to the different corn hybrids with different characteristics and different harvest times. In this experiment, the $24 \mathrm{~h}$ and $48 \mathrm{~h} \mathrm{DMD}$ is and $\mathrm{NDFD}_{\text {is }}$ were higher in the dual-purpose corn, while the ADL was higher in the silage-specific corn. This might be because of a high content of ADL that inhibited both the $\mathrm{DMD}_{\text {is }}$ [36] and $\mathrm{NDFD}_{\text {is }}$ [18]. Additionally, the $48 \mathrm{~h} \mathrm{DMD}$ is was higher than the $24 \mathrm{~h} \mathrm{DMD}$ is, suggesting that some nutrients may not be adequately digested following $24 \mathrm{~h}$ of fermentation.

The silage-specific corn with tall plants has less resistance to wind as compared to the dual-purpose corn. However, the necessary conditions for plant growth were favourable in our study, and no strong wind effect was noticed until harvesting. However, strong winds and an insufficient supply of water and fertilizer will lead to a serious lodging condition, and under these conditions, the yield of nutritive value per ha cannot be expected to be higher in silage-specific corn. Therefore, the specific weather conditions should be combined with the region to carefully choose corn for planting.

\section{Conclusions}

Altogether, we concluded that corn hybrid type had significant effects on the fermentation quality, chemical composition, yield production and energy value, carbohydrate profile, and in situ digestibility of whole-plant silage. Although the fermentation quality of the two corn hybrid types was good, comparatively, the ratio of lactic acid to acetic acid, 
propionic acid, Flieg point, EE, starch, $\mathrm{MA}, \mathrm{CB} 1$, and $\mathrm{DMD}_{\text {is }}$ of the dual-purpose corn silage were higher than in the silage-specific corn, while the NDF, ADF, ADL, DM yield per ha, MT, CB2, and CC were higher in the silage-specific corn silage. Thus, in the present study, we concluded that under favourable production conditions the nutritive value per unit is higher in dual-purpose corn silage, but the biomass yield and nutritive value per ha were higher in the silage-specific corn silage. In the future, feeding experiments are needed to verify this conclusion in combination with production performance and animal health status.

Author Contributions: Z.Z., Q.M. and H.W. designed this experiment and reviewed the manuscript. Y.L. and G.W. conducted the experiment and analyzed the data. Y.L. wrote the manuscript. M.Z.K. edited the article and revised the language. Z.Z. was responsible for the final content. All authors have read and agreed to the published version of the manuscript.

Funding: This study was supported by the government purchased services (16200158), China Agricultural Research System of MOF and MARA (CARS-37), Public Welfare Industry (Agriculture) and Application, and Demonstration of Whole-Plant Corn Silage (21177232). The authors also thank Beef Cattle Research Center staffs for their help in sampling and laboratory analysis.

Institutional Review Board Statement: The study approved by the Institutional Review Board of the China Agricultural University Animal Care and Use Committee (AW06059102-2, 20 August 2016, Beijing, China).

Data Availability Statement: All data are presented in the text and tables of this manuscript.

Acknowledgments: Authors are thankful to the government purchased services, China Agricultural Research System of MOF and MARA, Public Welfare Industry (Agriculture) and Application, and Demonstration of Whole-Plant Corn Silage for financial support and staffs of Beef Cattle Research Center for their help in sampling and laboratory analysis.

Conflicts of Interest: The authors declare no conflict of interest.

\section{References}

1. Bertoia, L.M.; Aulicino, M.B. Maize forage aptitude: Combining ability of inbred lines and stability of hybrids. Crop. J. 2014, 2, 407-418. [CrossRef]

2. Hart, K.J.; Huntington, J.A.; Wilkinson, R.G.; Bartram, C.G.; Sinclair, L.A. The influence of grass silage-to-maize silage ratio and concentrate composition on methane emissions, performance and milk composition of dairy cows. Animals 2015, 9, 983-991. [CrossRef] [PubMed]

3. Keady, T.W.J.; Hanrahan, J.P.; Marley, C.L.; Scollan, N.D. Production and utilization of ensiled forages by beef cattle, dairy cows, pregnant ewes and finishing lambs. Agric. Food Sci. 2013, 22, 70-92. [CrossRef]

4. Akins, M.; Shaver, R. Influence of corn silage hybrid type on lactation performance by Holstein dairy cows. J. Dairy Sci. 2014, 97, 7811-7820. [CrossRef]

5. FAO. The Database of Food Agriculture Organization. 2017. Available online: http:///www.fao.org/statistics.amis-outlook.org/ data/index.html (accessed on 3 April 2017).

6. Sheaffer, C.C.; Halgerson, J.L.; Jung, H.G. Hybrid and N fertilization affect corn silage yield and quality. J. Agron. Crop Sci. 2006, 192, 278-283. [CrossRef]

7. Ferraretto, L.F.; Crump, P.M.; Shaver, R.D. Effect of ensiling time and exogenous protease addition to whole-plant corn silage of various hybrids, maturities, and chop lengths on nitrogen fractions and ruminal in vitro starch digestibility. Pro. Anim. Scient. 2015, 31, 146-152. [CrossRef]

8. Thomas, E.D.; Mandebvu, P.; Ballard, C.S.; Sniffen, C.J.; Carter, M.P.; Beck, J. Comparison of corn silage hybrids for yield, nutrient composition, in vitro digestibility, and milk yield by dairy cows. J. Dairy Sci. 2001, 84, 2217-2226. [CrossRef]

9. Ballard, C.S.; Thomas, E.D.; Tsang, D.S.; Mandebvu, P.; Sniffen, C.J.; Endres, M.I.; Carter, M.P. Effect of corn silage hybrid on dry matter yield, nutrient composition, in vitro digestion, intake by dairy heifers, and milk production by dairy cows. J. Dairy Sci. 2001, 84, 442-452. [CrossRef]

10. Hunt, C.W.; Kezar, W.; Vinande, R. Yield, chemical composition, and ruminai fermentability of corn whole plant, ear, and stover as affected by hybrid. J. Prod. Agric. 1989, 5, 286-290. [CrossRef]

11. Wolf, D.P.; Coors, J.G.; Albrecht, K.A.; Undersander, D.J.; Carter, P.R. Agronomic evaluations of maize genotypes selected for extreme fiber concentrations. Crop Sci. 1993, 33, 1353-1359. [CrossRef]

12. Kilic, A. Silo Feed (Instruction, Education and Application Proposals); Bilgehan Press: Lzmir, Turkey, $1986 ;$ p. 327.

13. Association of Official Analytical Chemists (AOAC). Official Methods of Analysis, 17th ed.; Association of Official Analytical Chemists: Arlington, VA, USA, 2000. 
14. Van Soest, P.J.; Robertson, J.B.; Lewis, B.A. Methods for dietary fiber, neutral detergent fiber, and nonstarch polysaccharides in relation to animal nutrition. J. Dairy Sci. 1991, 74, 3583-3597. [CrossRef]

15. Robertson, J.B.; Van Soest, P.J. The detergent system of analysis and its application to human foods. In The Analysis of Dietary Fiber in Food; James, W.P.T., Theander, O., Eds.; Marcel Dekker Inc.: New York, NY, USA, 1981; pp. 123-142. [CrossRef]

16. Dubois, M.; Gilles, K.A.; Hamilton, J.K.; Rebers, P.A.; Smith, F. Colorimetric method for determination of sugars and related substances. Anal. Chem. 1956, 28, 350-356. [CrossRef]

17. Weiss, W.P. Predicting energy values of feeds1. J. Dairy Sci. 1993, 76, 1802-1811. [CrossRef]

18. NRC (National Research Council). Nutrient Requirements of Beef Cattle, 8th ed.; National Academy of Sciences: Washington, DC, USA, 2016

19. Sniffen, C.J.; Oconnor, J.D.; Vansoest, P.J.; Fox, D.G.; Russell, J.B. A net carbohydrate and protein system for evaluating cattle diets.2.carbohydrate and protein availability. J. Anim. Sci. 1992, 70, 3562-3577. [CrossRef]

20. Fei, W.; Li, D.Y.; Meng, Q.X. Technical note: A special apparatus for facilitating the in situ nylon bag measurement of the ruminal degradation of feedstuffs in cattle. J. Anim. Sci. 2016, 94, 3457-3463. [CrossRef]

21. NRC (National Research Council). Nutrient Requirements of Beef Cattle, 7th ed.; National Academy of Sciences: Washington, DC, USA, 2000.

22. Keady, T.; Lively, F.O.; Kilpatrick, D.J.; Moss, B.W. Effects of replacing grass silage with either maize or whole-crop wheat silages on the performance and meat quality of beef cattle offered two levels of concentrates. J. Anim. Sci. 2007, 1, 613-623. [CrossRef]

23. Tassone, S.; Fortina, R.; Peiretti, P.G. In Vitro techniques using the DaisyII incubator for the assessment of digestibility: A review. Animals 2020, 10, 775. [CrossRef]

24. Shao, T.; Zhang, Z.X.; Shimojo, M.; Wang, T.; Masuda, Y. Comparison of fermentation characteristics of Italian ryegrass (Lolium multiflorum Lam.) and guineagrass (Panicum maximum Jacq.) during the early stage of ensiling. Asian Austral. J. Anim. 2005, 18, 1727-1734. [CrossRef]

25. Anders, B.; Karin, J.; Katrin, S.M.; Johan, S. Metabolite profiles of lactic acid bacteria in grass silage. Appl. Environ. Microbiol. 2007, 73, 5547-5552. [CrossRef]

26. Nennich, T.D.; Linn, J.G.; Johnson, D.G.; Endres, M.I.; Jung, H.G. Comparison of feeding corn silages from leafy or conventional corn hybrids to lactating dairy cows. J. Dairy Sci. 2003, 86, 2932-2939. [CrossRef]

27. Zhou, Y.; Drouin, P.; Lafrenière, C. Effect of temperature $\left(5-25^{\circ} \mathrm{C}\right)$ on epiphytic lactic acid bacteria populations and fermentation of whole-plant corn silage. J. Appl. Microbiol. 2016, 121, 657-671. [CrossRef] [PubMed]

28. Brüning, D.; Gerlach, K.; Weiß, K.; Südekum, K.H. Effect of compaction, delayed sealing and aerobic exposure on maize silage quality and on formation of volatile organic compounds. Grass Forage Sci. 2018, 73, 53-66. [CrossRef]

29. Shaver, R.D.; Shinners, K.J.; Coors, J.G. Stage of maturity, processing, and hybrid effects on ruminal in situ disappearance of whole-plant corn silage. Anim. Feed. Sci. Technol. 2000, 86, 83-94. [CrossRef]

30. Johnson, L.M.; Harrison, J.H.; Davidson, D.; Robutti, J.L.; Swift, M.; Mahanna, W.C.; Shinners, K. Corn silage management I: Effects of hybrid, maturity, and mechanical processing on chemical and physical characteristics. J. Dairy Sci. 2002, 85, 833-853. [CrossRef]

31. Xu, S.; Harrison, J.H.; Kezar, W.; Entrikin, N.; Loney, K.A.; Riley, R.E.; Bush, L.J.; Guthrie, L.D.; Hunt, C. Evaluation of yield, quality, and plant composition of early-maturing corn hybrids harvested at three stages of maturity. Prof. Anim. Sci. 1995, 11, 157-165. [CrossRef]

32. Benefield, B.C.; Liñeiro, M.; Ipharraguerre, I.R.; Clark, J.H. NutriDense corn grain and corn silage for dairy cows. J. Dairy Sci. 2006, 89, 1571-1579. [CrossRef]

33. Lynch, J.P.; O'Kiely, P.; Doyle, E.M. Yield, quality and ensilage characteristics of whole-crop maize and of the cob and stover components: Harvest date and hybrid effects. Grass Forage Sci. 2012, 67, 472-487. [CrossRef]

34. Hall, M.B.; Eastridge, M.L. Carbohydrate and fat: Considerations for energy and more. Pro. Anim. Sci. 2014, 30, 140-149. [CrossRef]

35. Gruber, L.; Terler, G.; Knaus, W. Nutrient composition, ruminal degradability and whole tract digestibility of whole crop maize silage from nine current varieties. Arch. Anim. Nutr. 2018, 72, 121-137. [CrossRef]

36. Olubajo, F.O.; Soest, P.J.V.; Oyenuga, V.A. Comparison and digestibility of four tropical grasses grown in Nigeria. J. Anim. Sci. 1974, 38, 149-153. [CrossRef] 